\title{
Assessment of Undiscovered Oil and Gas Resources of the Chad Basin Province, North-Central Africa
}

\begin{abstract}
The Chad Basin Province located in north-central Africa recently was assessed for undiscovered, technically recoverable oil, natural gas, and natural gas liquids resources as part of the U.S. Geological Survey's (USGS) World Oil and Gas Assessment. Using a geology-based assessment methodology, the USGS estimated mean volumes of 2.32 billion barrels of oil, 14.65 trillion cubic feet of natural gas, and 391 million barrels of natural gas liquids.
\end{abstract}

\section{Introduction}

The main objective of the U.S. Geological Survey's (USGS) World Petroleum Resources Project is to assess the potential for undiscovered, technically recoverable oil and natural gas resources of the world, exclusive of the United States. As part of this program, the USGS recently completed an assessment of the Chad Basin Province (fig. 1). The Chad Basin is the largest intracratonic basin in north-central Africa that was influenced by Cretaceous and Tertiary rifting. The province covers an area of approximately $1,145,000$ square kilometers $\left(\mathrm{km}^{2}\right)$ and includes parts of Algeria, Cameroon, Chad, Niger, and Nigeria. This assessment was based on data from oil and gas wells and fields, field production records, and published geologic reports. At the time of the assessment, the province contained eight oil fields - three in Chad and five in Niger - and is considered to be underexplored for its size. There are no gas fields in the province but several discoveries were reported to have associated gas. The oil fields and recent discoveries are limited to the CretaceousTertiary rift basins of Chad and Niger.

The Chad Basin Province was assessed for the first time because of increased exploratory activity and interest in its future potential. The assessment was based on geology and used the total petroleum system (TPS) concept. The geologic elements of a TPS include hydrocarbon source rocks (source rock maturation and hydrocarbon generation and migration), reservoir rocks (quality and distribution), and traps for hydrocarbon accumulation. Using these geologic criteria, the USGS defined the Cretaceous-Tertiary Composite TPS with one assessment unit (AU), the Cretaceous-Tertiary Rifts AU (fig. 1), encompassing about $415,000 \mathrm{~km}^{2}$. The TPS was defined to include Cretaceous and Tertiary lacustrine and marine source rocks and the AU contains Cretaceous and Tertiary clastic reservoirs, shale seals, and traps that mostly are structural.

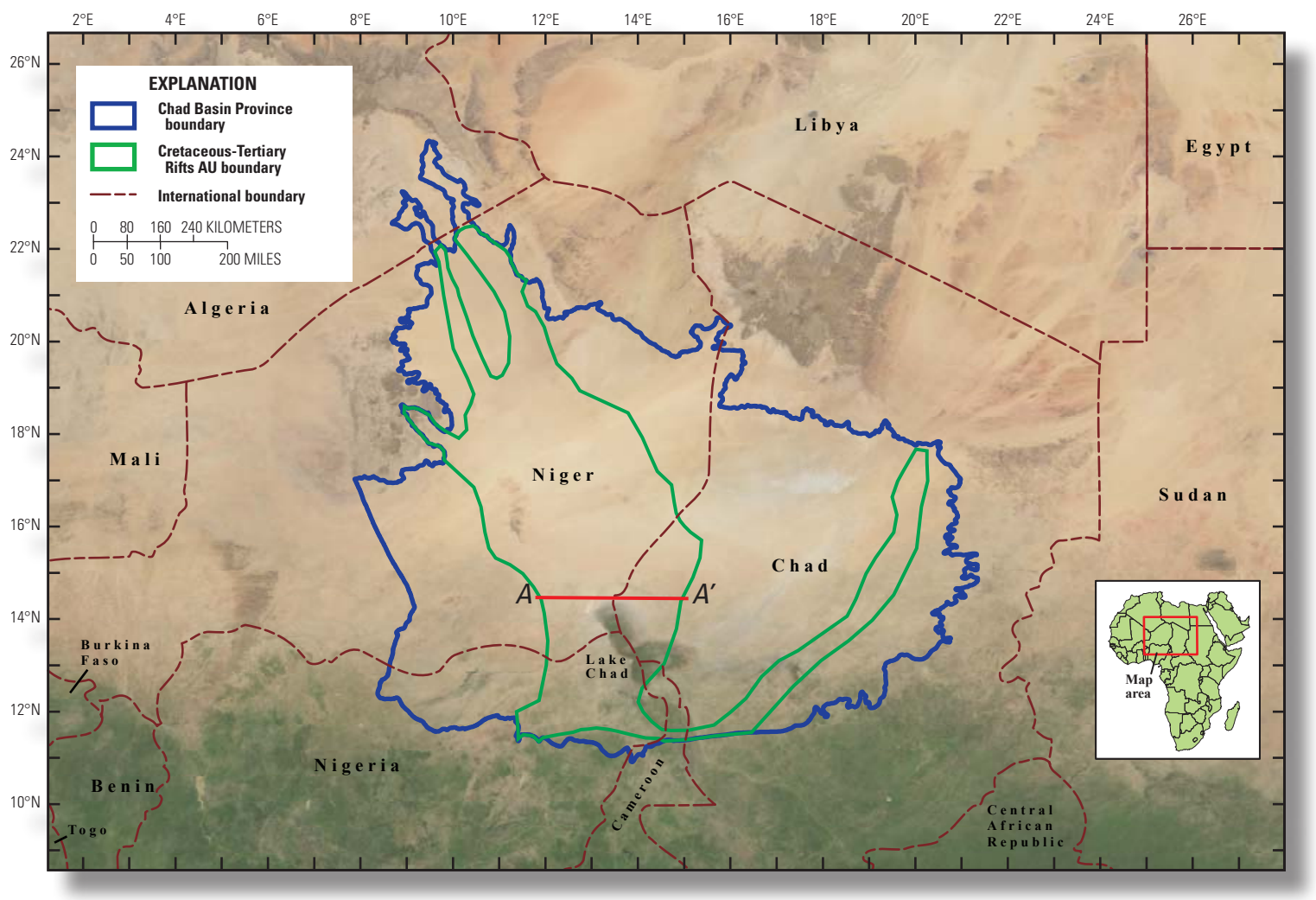

Figure 1. Locations of the Chad Basin Province and the CretaceousTertiary Rifts Assessment Unit (AU). Cross section $A-A^{\prime}$ shown in figure 2. 
The Cretaceous-Tertiary rift basins are filled with Lower Cretaceous to Neogene sedimentary rocks, ranging in thickness from about 3,000 meters (m) to more than 12,000 m (fig. 2) that were deposited in fluvial, lacustrine, and marine environments (Genik, 1992; Genik, 1993; Zanguina and others, 1998). During the Early Cretaceous fluvial and lacustrine rocks were deposited in the rift basins of the Chad Basin. In the Late Cretaceous (Cenomanian to Maastrichtian) there was a marine transgression resulting from a regional sag event that formed a broad basin in which shallow marine to marginal marine and coastal plain rocks accumulated. During the Late Cretaceous to Oligocene, the last rifting phase occurred in the Chad Basin and thick fluvial and lacustrine rocks were deposited. The rift basins are known to contain Cretaceous and Tertiary lacustrine and marine source rocks that have generated hydrocarbons since the Late Cretaceous (Genik, 1993). The generated hydrocarbons migrated into Cretaceous and Tertiary reservoirs and structural traps.

\section{References}

Genik, G.J., 1992, Regional framework, structural and petroleum aspects of rift basins in Niger, Chad and the Central African Republic (C.A.R.): Tectonophysics, v. 213, no. 1, p. 169-185.

Genik, G.J., 1993, Petroleum geology of the CretaceousTertiary rifts basins in Niger, Chad, and Central African Republic: American Association of Petroleum Geologists Bulletin v. 77 , no. 8 , p. 1405-1434.

Zanguina, M., Bruneton, A., and Gonnard, R., 1998, An introduction to the petroleum potential of Niger: Journal of Petroleum Geology, v. 21, no. 1, p. 83-103.

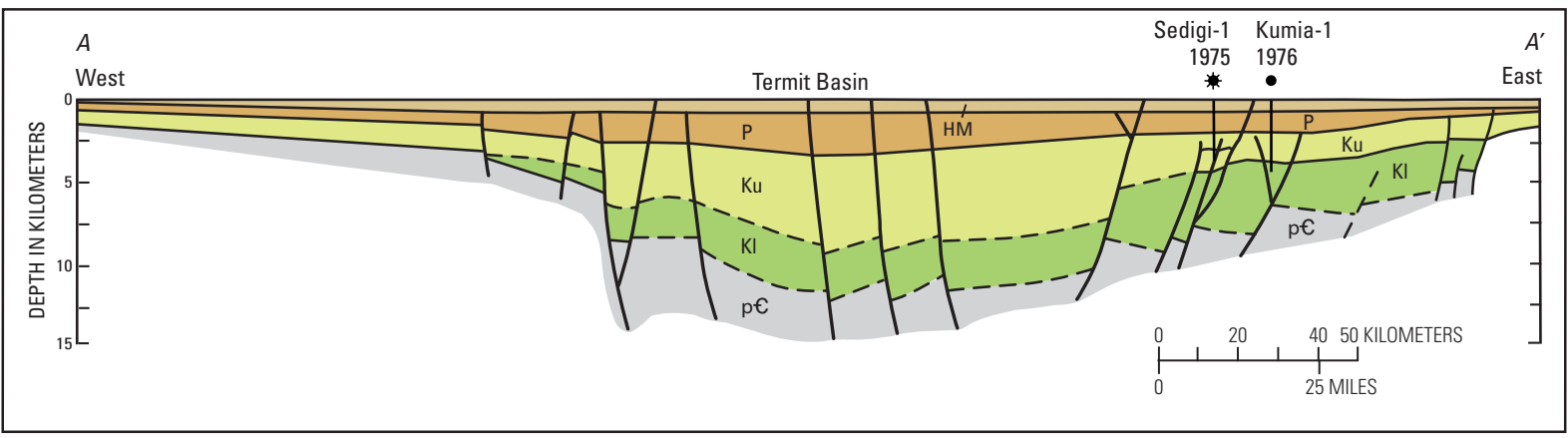

Figure 2. Schematic cross section showing the sedimentary fill of the southern part of the Termit rift basin in the Chad Basin Province, north-central Africa. Location of cross section shown in figure 1. p€, Precambrian; KI, Lower Cretaceous; Ku, Upper Cretaceous; P, Paleogene; HM, Holocene to Miocene. Modified after Genik (1993).

\section{Resource Summary}

Using a geology-based assessment, the USGS estimated mean volumes of undiscovered, technically recoverable conventional oil and gas resources for the Cretaceous-Tertiary Rifts AU in the Chad Basin Province (table 1). The mean volumes are estimated at 2,315 million barrels of oil (MMBO), 14,648 billion cubic feet of gas (BCFG), and 391 million barrels of natural gas liquids. The estimated mean size of the expected largest oil field is $387 \mathrm{MMBO}$ and the estimated mean size of the expected largest gas field is 2,320 BCFG.

\section{For Additional Information}

Assessment results are available at the USGS Central Energy Resources Science Center Web site: http://energy.cr.usgs. gov/oilgas/noga/ or contact Michael E. Brownfield, the assessing geologist (mbrownfield@usgs.gov).

\section{Chad Basin Provinces Assessment Team}

Michael E. Brownfield, Christopher J. Schenk, Ronald R. Charpentier, Timothy R. Klett, Troy A. Cook, Richard M. Pollastro, and Marilyn E. Tennyson.

Table 1. Chad Provinces assessment results for undiscovered, technically recoverable oil, gas, and natural gas liquids.

[Largest expected mean field size in million barrels of oil and billion cubic feet of gas; MMBO, million barrels of oil. BCFG, billion cubic feet of gas. MMBNGL, million barrels of natural gas liquids. Results shown are fully risked estimates. For gas accumulations, all liquids are included as natural gas liquids (NGL). Undiscovered gas resources are the sum of nonassociated and associated gas. F95 represents a 95 percent chance of at least the amount tabulated; other fractiles are defined similarly. AU, assessment unit; AU probability is the chance of at least one accumulation of minimum size within the AU. NGL, natural gas liquids. TPS, total petroleum system. Gray shading indicates not applicable]

\begin{tabular}{|c|c|c|c|c|c|c|c|c|c|c|c|c|c|c|}
\hline \multirow{3}{*}{$\begin{array}{l}\text { Province, Total Petroleum } \\
\text { Systems (TPS) and } \\
\text { Assessment Unit (AU) }\end{array}$} & \multirow{3}{*}{$\begin{array}{l}\text { Field } \\
\text { Type }\end{array}$} & \multirow{3}{*}{$\begin{array}{l}\text { Largest } \\
\text { Expected } \\
\text { Mean } \\
\text { Field Size }\end{array}$} & \multicolumn{12}{|c|}{ Total Undiscovered Resources } \\
\hline & & & \multicolumn{4}{|c|}{ Oil (MMBO) } & \multicolumn{4}{|c|}{ Gas (BCFG) } & \multicolumn{4}{|c|}{ NGL (MMBNGL) } \\
\hline & & & F95 & F50 & F5 & Mean & F95 & F50 & F5 & Mean & F95 & F50 & F5 & Mean \\
\hline \multirow{2}{*}{ Cretaceous-Tertiary Rifts AU } & Oil & 387 & 794 & 2,082 & 4,637 & 2,315 & 228 & 657 & 1,665 & 766 & 6 & 18 & 46 & 21 \\
\hline & Gas & 2,320 & & & & & 4,786 & 12,443 & 28,002 & 13,882 & 125 & 330 & 751 & 370 \\
\hline
\end{tabular}

